\title{
Practical Method for Parallel Synthesis of Diversely Substituted 1-Phenylpiperazines
}

Igor Konstantinov, Konstantin Bukhryakov,Yuri Gezentsvey and Mikhail Krasavin*

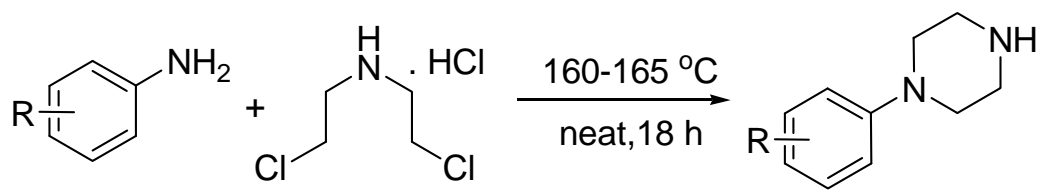

$$
33 \text { examples }
$$

A simple and practical method to prepare 'libraries' of substituted 1-phenylpiperazine building blocks in parallel format have been developed. 


\title{
Practical Method for Parallel Synthesis of Diversely Substituted 1-Phenylpiperazines
}

Igor Konstantinov, ${ }^{a}$ Konstantin Bukhryakov, ${ }^{a}$ Yuri Gezentsvey ${ }^{a}$ and Mikhail Krasavin* ${ }^{a, b} \S$

${ }^{a}$ Chemical Diversity Research Institute, 2a Rabochaya St., Khimki, Moscow Reg., 141400, Russia

${ }^{b}$ Science and Education Center “Innovative Research”, Yaroslavl State Pedagogical University, 150000, Russia

*Corresponding author, e-mail: myk@chemdiv.com, phone: +7(495)995-4944, fax: +7(495)6269780 .

${ }^{\S}$ Current address: Eskitis Institute, Griffith University, Brisbane, QLD 4111 Australia.

\begin{abstract}
A simple and practical method to prepare 'libraries' of substituted 1-phenylpiperazine building blocks in parallel format have been developed.
\end{abstract}

Keywords: $N$-arylpiperazines, bis-alkylation, nitrogen mustard, parallel synthesis, solvent-free synthesis

\section{INTRODUCTION}

1-Arylpiperazines constitute an important class of structural motifs in CNS drug discovery. Compounds based on the privileged [1] 1-arylpiperazine scaffold have been reported, to mention a few examples, as melanocortin MC4 receptor agonists [2], serotonin 5- $\mathrm{HT}_{1 \mathrm{~A}}$ receptor antagonists [3], dopamine $\mathrm{D}_{2}$ receptors modulators [4].

In the course of a lead optimization program conducted in our laboratories, we recently required a rapid access to a large set of diversely substituted 1-phenylpiperazines to explore structureactivity relationships (SAR) via variations in the active compound's periphery. While hundreds of these secondary amine building blocks can potentially be acquired via commercial sources, certain SAR-informative 1-phenylpiperazines need to be synthesized from the respective (usually more available) anilines. 
Several methods to convert anilines into the respective 1-phenylpiperazines appeared in the literature, typically employing 2-chloro- $N$-(2-chloroethyl)ethanamine (used as hydrochloride [5] or in an alkoxycarbonyl-protected form [6]) as a five-atom synthon to form the piperazine cycle. In some cases, the more reactive bromide counterpart of this reagent was used [7] or the reaction was conducted in the presence of an iodide salt to catalyze the process [8]. As a more benign alternative to the 'nitrogen mustard'-type reagents, 2,2'-iminodiethanol [9] or morpholine [10] could be used.

For our needs, however, we required a general and practical method that would allow preparing dozens of the requisite 1-arylpiperazines as 'libraries' of building blocks, in parallel format. Having attempted the existing literature methods to this end and found them to lack the desired practicality, we developed an alternative method to convert anilines into substituted 1phenylpiperazines that we disclose herein.

\section{RESULTS AND DISCUSSION}

For each of the parallel reactions (Scheme 1), a $10 \mathrm{~mL}$ vial equipped with a magnetic stirrer was charged with an aniline (1, $7.6 \mathrm{mmol})$ and 2-chloro- $N$-(2-chloroethyl)ethanamine hydrochloride (2, $8.4 \mathrm{mmol})$. The dry solids were thoroughly mixed, each vial was capped with a pierced septum (to allow the gas evolution) and placed in a room-temperature oil bath. The temperature of the bath was raised to $160-165{ }^{\circ} \mathrm{C}$ over $30 \mathrm{~min}$. The solids melted and slow evolution of the hydrogen chloride gas was observed over the next 1-2 hours. The reaction mixtures were kept at that temperature overnight and then were cooled down to room temperature. The glass-like reaction mixtures were treated with acetone $(5 \mathrm{~mL})$ and placed on a $45{ }^{\circ} \mathrm{C}$ ultrasonic bath for 3-4 h. The resulting fine solids were filtered off, each placed in a $100 \mathrm{~mL}$ round-bottomed flask and stirred with 3M aqueous sodium hydroxide solution $(10 \mathrm{~mL})$ and ether $(60 \mathrm{~mL})$. The biphasic mixtures were filtered; the organic layers were separated, washed with water ( $3 \times 15 \mathrm{~mL})$, dried over anhydrous $\mathrm{Na}_{2} \mathrm{SO}_{4}$, filtered, and treated with $4 \mathrm{M}$ solution of $\mathrm{HCl}$ in dioxane. The resulting precipitates were collected by filtration, washed with cold acetone and air-dried. The crude 1phenylpiprazines $\mathbf{3}$ were crystallized from methanol to provide analytically pure compounds [11] in moderate to good yields (Table 1). 
The scope of this method is quite general with respect to substituted anilines. The method is practically simple and can potentially be amended to an automated format. In a limited period of time, it allowed us to create a substantial arsenal of 1-phenylpiperazines on a scale of 500 mg. The only limitation of this method that we have note so far is its failure to give the desired products 3 for anilines containing basic motifs as well as for some poorly reactive heteroaromatic amines (Fig. 1).

\section{CONCLUSION}

In summary, we have developed a practical method to prepare 'libraries' of medicinally important substituted 1-phenylpiperazine building blocks in parallel format. The method appears to have superior practicality to the literature methods reported hitherto.

\section{ACKNOWLEGEMENT}

This research was supported by the Federal Agency for Science and Innovation (Russian Federation Government Contract 02.740.11.0092).

\section{REFERENCES AND NOTES}

[1] Duarte, C. D.; Barreiro, E. J.; Fraga, C. A. Privileged structures: a useful concept for the rational design of new lead drug candidates. Mini Rev. Med. Chem., 2007, 7, 1108-1119.

[2] Dyck, B.; Parker J.; Phillips, T.; Carter, L.; Murphy, B.; Summers, R.; Hermann, J.; Baker, T.; Cismowski, M.; Goodfellow, V. Aryl piperazine melanocortin MC4 receptor agonists. Bioorg. Med. Chem. Lett., 2003, 13, 3793-3796.

[3] Chojnacka-Wojcik, E.; Klodzinska, A.; Drabazynska, A.; Pawlowski, M.; CharakchievaMinol, S.; Chlon, G.; Goczyca, M. A new putative 5- $\mathrm{HT}_{1 \mathrm{~A}}$ receptor antagonist of the 1arylpiperazine class of ligands. Eur. J. Med. Chem., 1995, 30, 587-592.

[4] Taverne, T.; Diouf, O.; Depreux, P.; Poupaert, J. H.; Lesieur, D.; Guardiola-Lemaitre, B.; Rettori, M.-C.; Caignard, D.-H.; Pfeiffer, B. Novel Benzothiazolin-2-one and Benzoxazin-3one Arylpiperazine Derivatives with Mixed $5 \mathrm{HT}_{1 \mathrm{~A}} / \mathrm{D}_{2}$ Affinity as Potential Atypical Antipsychotics. J. Med. Chem., 1998, 41, 2010-2018. 
[5] Lyon, R. A.; Titeler, M.; McKenney, J. D.; Magee, P. S.; Glennon, R. A. Synthesis and evaluation of phenyl- and benzoylpiperazines as potential serotonergic agents. J. Med. Chem., 1986, 29, 630-634.

[6] Lee, M.; Rangisetty, J. B.; Pullagurla, M. R.; Dukat, M.; Setola, V.; Roth, B. L.; Glennon, R. A. 1-(1-Naphthyl)piperazine as a novel template for 5-HT6 serotonin receptor ligands. Bioorg. Med. Chem. Lett., 2005, 15, 1707-1711.

[7] Tominaga, M.; Yo, E.; Ogawa, H.; Yamashita, S.; Yabuuchi, Y.; Nakagawa, K. Synthesis of 3,4-dihydro-6-[4-(3,4-dimethoxybenzoyl)-1-piperizinyl]-2(1H)-quinolone and related compounds. Chem. Pharm. Bull., 1984, 32, 2100-2110.

[8] Favor, D. A.; Johnson, D. S.; Powers, J. J.; Li, T.; Madabattula, R. Synthesis of chromanyl and dihydrobenzofuranyl piperazines. Tetrahedron Lett., 2007, 48, 3039-3041.

[9] Robarge, M. J.; Husbands, S. M.; Kieltyka, A.; Brodbeck, R.; Thurkauf, A.; Newman, A. H. Design and Synthesis of [(2,3-Dichlorophenyl)piperazin-1-yl]alkylfluorenylcarboxamides as Novel Ligands Selective for the Dopamine $\mathrm{D}_{3}$ Receptor Subtype. J. Med. Chem., 2001, 44, 3175-3186.

[10] Koppe, V.; Poetsch, E.; Schulte, K. Substituted 4-phenyl-1-(3-pyrazolylalkyl)piperazines. Eur. J. Med. Chem., 1975, 10, 154-161.

[11] Characterization data for selected compounds: $3 \mathbf{b}-{ }^{1} \mathrm{H}$ NMR (300 MHz, $d_{6}$-DMSO) $\delta$ 7.22 (br s, $\mathrm{NH}+$ bound $\mathrm{H}_{2} \mathrm{O}$ ), 6.81 (s, 2H), 6.67 (s, 1H), $3.49(\mathrm{~m}, 4 \mathrm{H}), 3.28(\mathrm{~m}, 4 \mathrm{H}), 2.22$ (s, $6 \mathrm{H}) ;{ }^{13} \mathrm{C}$ NMR (75 MHz, $d_{6}$-DMSO) $\delta$ 147.8, 138.5, 124.3, 115.3, 46.9, 41.8, 21.1; LC MS $\left[\mathrm{M}+\mathrm{H}^{+}\right] \mathrm{m} / \mathrm{z}$ 191.4; $3 \mathbf{i}-{ }^{1} \mathrm{H}$ NMR (300 MHz, $d_{6}$-DMSO) $\delta 9.60$ (br s, $\mathrm{NH}+$ bound $\mathrm{H}_{2} \mathrm{O}$ ), 7.13 (t, $J=7.4 \mathrm{~Hz}, 1 \mathrm{H}), 6.68$ (d, $J=7.4 \mathrm{~Hz}, 1 \mathrm{H}), 6.75-6.80$ (m, 2H), 3.36 (m, 4H), 3.15 (m, 4H), 2.54 (q, $J=7.6 \mathrm{~Hz}, 2 \mathrm{H}), 1.14$ (t, $J=7.6 \mathrm{~Hz}, 3 \mathrm{H}) ;{ }^{13} \mathrm{C}$ NMR (75 MHz, $d_{6}$-DMSO) $\delta 150.1$, 144.6, 128.9, 119.5, 115.6, 113.4, 45.4, 42.4, 28.4, 15.6; LC MS $\left[\mathrm{M}+\mathrm{H}^{+}\right] \mathrm{m} / \mathrm{z} 191.2$; 30 - ${ }^{1} \mathrm{H}$ NMR (300 MHz, $d_{6}$-DMSO) $\delta 9.68$ (br s, NH + bound $\mathrm{H}_{2} \mathrm{O}$ ), 7.21 (d, $J=6.5 \mathrm{~Hz}, 2 \mathrm{H}$ ), 7.06 (d, $J=6.5 \mathrm{~Hz}, 2 \mathrm{H}), 3.41$ (m, 4H), 3.16 (m, 4H); ${ }^{13} \mathrm{C}$ NMR (75 MHz, $d_{6}$-DMSO) $\delta$ 1148.9, 141.4, 121.9, 120.2 (q, $\left.J_{C-F}=190.2 \mathrm{~Hz}\right), 117.1,45.4,42.3$; LC MS $\left[\mathrm{M}+\mathrm{H}^{+}\right] \mathrm{m} / \mathrm{z} 247.2$. 
Scheme 1.

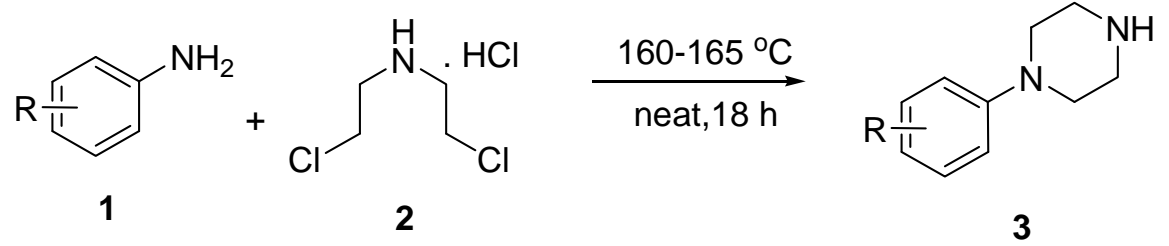

Figure 1. Examples of unreactive anilines and heteroaromatic amines.<smiles>CN1CCCc2ccc(N)cc21</smiles><smiles>Nc1ccccc1CCc1ccncc1</smiles><smiles>Nc1cnccn1</smiles><smiles>Nc1ccc(F)cn1</smiles><smiles>Nc1ccncc1</smiles><smiles>NC(=O)c1nonc1N</smiles> 
Table 1. Substituted 1-phenylpiperazines 3 synthesized in this work.

\begin{tabular}{|c|c|c|c|c|c|}
\hline Aniline 1 & Structure & Yield of 3, \% & Aniline 1 & Structure & Yield of 3, \% \\
\hline $\mathbf{a}$ & $\mathrm{H}_{2} \mathrm{~N}_{7}$ & 62 & n & & 63 \\
\hline b & $\mathrm{H}_{2} \mathrm{I}$ & 70 & $\mathbf{0}$ & & 62 \\
\hline c & $\mathrm{H}_{2} \mathrm{~N}$ & 40 & $\mathbf{p}$ & & 49 \\
\hline d & & 60 & $\mathbf{q}$ & & 52 \\
\hline e & $\mathrm{H}_{2} \mathrm{I}$ & 45 & $\mathbf{r}$ & & 46 \\
\hline f & $\mathrm{H}_{2} \mathrm{I}$ & 38 & $\mathbf{s}$ & & 74 \\
\hline g & $\mathrm{H}_{2} \mathrm{~N}$ & 27 & $\mathbf{t}$ & & 45 \\
\hline h & $\mathrm{H}_{2} \mathrm{~N}$ & 67 & $\mathbf{u}$ & & 43 \\
\hline i & $\mathrm{H}_{2} \mathrm{~N}$ & 75 & $\mathbf{v}$ & & 30 \\
\hline $\mathbf{j}$ & $\mathrm{H}_{2} \mathrm{~N}$ & 55 & $\mathbf{w}$ & & 35 \\
\hline $\mathbf{k}$ & $\mathrm{H}_{2} \mathrm{~N}$ & 35 & $\mathbf{x}$ & & 34 \\
\hline I & & 27 & $\mathbf{y}$ & & 51 \\
\hline $\mathbf{m}$ & & 50 & $\mathbf{z}$ & & 67 \\
\hline
\end{tabular}

